\title{
PENINGKATAN KUALITAS PELAYANAN KESEHATAN DI KLINIK HARMONY YOGYAKARTA
}

\author{
Wisnu Kartika, Nur Hudha Wijaya, Hanifah Rahmi Fajrin \\ Program Vokasi, Prodi Teknik Elektromedik, Universitas Muhammadiyah Yogyakarta \\ wisnu2007@umy.ac.id
}

DOI : 10.31604/jpm.v2i1.36-39

\begin{abstract}
At this time, more and more culinary variations (food), causing various kinds of diseases and symptoms of the disease if we consume it too much. With this problem, many people will go to the hospital. At this time, in addition to hospitals also developed Puskesmas and small clinics both at the Village, Village and District levels. The clinic is divided into various types, namely public clinics and dental clinics. Clinics and Puskesmas provide medical equipment to help cure patients or for medical treatment. This service aims to improve or provide recommendations on whether medical devices at the clinic are still feasible to be replaced or still good. Some examples of medical devices are tensimeter, thermometer, baby scales, stethoscope, and adult scales. Tensimeter consists of several types, namely tensimeter needle, tensimeter mercury and now has developed a digital tensimeter. The service performed at this clinic is to identify the tensimeter and thermometer equipment that still exists, if there is damage, repairs will be made. The results of this service found damage to three tensimeter mercury. The conclusion that can be obtained from this service is that with this service program, we can help the clinic.
\end{abstract}

Keywords: Medical Electronics Technology, Medical, Medical Equipment, Healthy.

\begin{abstract}
Abstrak
Pada saat ini, semakin banyak variasi kuliner (makanan), sehingga menyebabkan berbagai macam penyakit maupun gejala penyakit jika kita mengkonsumsinya terlalu berlebihan. Dengan adanya masalah ini, maka akan banyak orang yang berobat ke rumah sakit. Pada masa ini, selain rumah sakit juga berkembang Puskesmas maupun klinik kecil baik ditingkat Desa, Kelurahan maupun Kecamatan. Klinik pun terbagi atas berbagai macam yaitu klinik umum dan klinik gigi. Klinik maupun Puskesmas menyediakan peralatan medis untuk membantu menyembuhkan pasien atau untuk tindakan medis. Pengabdian ini bertujuan untuk memperbaiki maupun memberikan rekomendasi apakah alat medis pada klinik tersebut masih layak untuk diganti atau masih baik. Beberapa contoh alat medis yaitu tensimeter, thermometer , timbangan bayi, stetoskop dan timbangan orang dewasa. Tensimeter terdiri atas beberapa jenis yaitu tensimeter jarum, tensimeter air raksa dan sekarang telah berkembang tensimeter digital. Pengabdian yang dilakukan pada klinik ini yaitu mengidentifikasi peralatan tensimeter dan thermometer yang masih ada, jika terdapat kerusakan maka akan dilakukan perbaikan. Hasil dari pengabdian ini ditemukan kerusakan pada tiga tensimeter air raksa. Kesimpulan yang dapat diperoleh dari pengabdian ini adalah dengan adanya program pengabdian ini maka kita dapat membantu klinik tersebut.
\end{abstract}

Kata kunci: Teknik Elektromedik, Kesehatan, Peralatan Kesehatan, Medis. 


\section{PENDAHULUAN}

Tensimeter pada umumnya ada beberapa jenis yaitu tensimeter jarum, tensimeter raksa(S. Huang, P. Hung, 2014) dan tensimeter digital(T. M. Seeberg et al., 2017). Tensimeter raksa adalah alat yang digunakan untuk mengukur tekanan darah pada manusia(K. Barbe, 2012). Tensimeter air raksa pertama kali ditemukan oleh oleh Nikolay Korotkov, ilmuwan asal Uni Soviet.

\section{METODE PELAKSANAAN}

\section{Standar Prosedur Oprasional (SPO)} Pemeliharaan Tensimeter Air Raksa

a. Persiapan
1) Siapkan Surat Perintah Kerja (SPK)
2) Siapkan lembar ceklist maintenace dan kartu pemeliharaan alat.

3) Siapkan buku Servis Manual.

4) Siapkan Protap pemeliharaan dan protap pengoperasian alat.

5) Siapkan peralatan kerja.

6) Tool set mekanik.

7) Wadah air raksa.

8) Pressure meter.

9) Siapkan bahan pemeliharaan, bahan operasional dan material bantu.

10) Contact cleaner.

11) Air Raksa.

12) Kain lap.

13) Manset.

14) Bulb/Balon tensi.

b. Pelaksanaan

1) Bersihkan seluruh bagian alat.

2) Cek fungsi manset, ganti bila perlu.

3) Cek fungsi balon, ganti bila perlu.
4) Cek posisi air raksa pada posisi nol.

5) Bersihkan air raksa, tabung skala dan tabung chambers air raksa.

6) Lakukan pengujian kinerja alat .

7) Kesimpulan hasil pemeliharaan.

c. Pencatatan

1) Lakukan pengisian lembar ceklist maintenance, kartu pemeliharaan.

2) Simpulkan hasil pemeliharaan

a) Alat layak pakai

b) Alat tidak layak pakai

3) Pengguna alat menandatangani lembar ceklist maintenance sebagai bukti pemeliharaan alat telah dilaksanakan.

\section{d. Pengemasan}

1) Cek alat kerja dan alat ukur, sesuaikan dengan lembar kerja.

2) Cek dan rapikan dokumen teknis penyerta.

3) Kembalikan alat kerja alat ukur dan dokumen teknis penyerta ke tempat semula.

4) Bersihkan lokasi pemeliharaan.

\section{Perbaikan Tensimeter Air Raksa}

a. Keluhan: Pengukuran tidak sesuai

b. Analisa : Air raksa kotor

c. Persiapan

1) Obeng

2) Wadah pembersih untuk tempat air raksa

3) Spet (jarum suntik)

4) Tisu

5) Lap atau kain

6) Lidi

7) Digital pressure meter

d. Langkah kerja

1) Membersihkan seluruh badan alat.

2) Mengeluarkan tabung skala. 
3) Membersihkan tabung air raksa menggunakan lidi dan tisu.

4) Membuka baut engsel dan membersihkan.

5) Mengeluarkan air raksa dari wadah cadangan air raksa dan pindahkan pada wadah tempat untuk pembersihan.

6) Memasukkan tisu kedalam spet sebagai penyaring pada saat melakukan pembersihan air raksa.

7) Memasukkan air raksa kedalam spet untuk melakukan pembersihan.

8) Menyaring air raksa dan tempatkan kembali pada wadah pembersihan.

Laporan hasil verifikasi tensimeter

1. Corona

Jenis Perbaikan : Pembersihan tabung dan penambahan air raksa

Kebocoran : $4.0 \mathrm{mmHg}$

2. Memasang kembali wadah cadangan air raksa dan baut engsel.

3. Memasang kembali tabung skala.

4. Memasukan air raksa menggunakan spet melalui lubang dibagian atas tabung skala sampai mencapai titik 0 .
5. Melakukan kalibrasi alat. (Geraldo, 2017)

\section{HASIL DAN PEMBAHASAN}

Kegiatan pengabdian ini dilaksanakan pada Tanggal 2 Juni 2018 bertempat di Klinik Harmony Yogyakarta. Kegiatan diisi dengan perbaikan alat kesehatan yang perlu perbaikan. Kami dari tim D3 Teknik Elektromedik membawa beberapa jenis peralatan maupun alat kesehatan yang akan digunakan dan diberikan pada Klinik Harmony. Kegiatan dimulai sekitar pukul 10 pagi dan diakhiri pukul 14 siang. Tim dari kami terdiri atas 3 orang Dosen dan 3 laboran dan beberapa mahasiswa tingkat akhir. Hasil dari pemeriksaan tim kami ditemukan beberapa tensimeter raksa (S. Liu, T. Lin, 2015) yang sudah tidak berfungsi dengan baik dan kami memperbaikinya(S. Baktash et al., 2017) (S. Ahmad et al., 2012) (M. Singh and N. Jain, 2016) (S. Ando, 2014). Kami juga mengganti beberapa manchet. Hasil pengujian pada alat sphygmomanometer merek Corona dapat dilihat pada Tabel 1.

Tabel 1. Uji Pengukuran Tensimeter

Keterangan $\quad$ Tensimeter dapat berfungsi dengan baik.

\begin{tabular}{|c|c|c|c|c|c|c|c|c|c|c|}
\hline \multirow[t]{3}{*}{ No. } & \multicolumn{10}{|c|}{ Pengukuran ke- } \\
\hline & \multicolumn{2}{|c|}{1} & \multicolumn{2}{|c|}{2} & \multicolumn{2}{|c|}{3} & \multicolumn{2}{|c|}{4} & \multicolumn{2}{|c|}{5} \\
\hline & Naik & Turun & Naik & Turun & Naik & Turun & Naik & Turun & Naik & Turun \\
\hline 1 & 0 & & 0 & & & & & & & \\
\hline 2 & 48.7 & 199.3 & 49.1 & 199.2 & & & & & & \\
\hline 3 & 97.1 & 148.0 & 98.5 & 148.5 & & & & & & \\
\hline 4 & 148.5 & 98.6 & 149.1 & 99.0 & & & & & & \\
\hline 5 & 199.3 & 50.7 & 199.2 & 50.2 & & & & & & \\
\hline \multirow[t]{2}{*}{6} & & 0.2 & & 0.1 & & & & & & \\
\hline & & & & Rata-ra & Kesa & han Pen & ikuran & \multicolumn{3}{|c|}{$0.6333 \mathrm{mmHg}$} \\
\hline
\end{tabular}


KESIMPULAN

Dengan menggunakan adanya
pengabdian ini dapat $\begin{array}{r}\text { diambil } \\ \text { kesimpulan bahwa }\end{array}$ membantu
meringankan permasalahan kerusakan
alat pada klinik. Menambah kerjasama
jejaring klinik dengan pihak
Universitas. Menambah pengalaman
praktik di lapangan langsung bagi
mahasiswa

\section{UCAPAN TERIMA KASIH}

Kami mengucapkan terima kasih kepada Program Studi D3 Teknik Elektromedik dan Program Vokasi UMY yang telah memberikan support.

\section{DAFTAR PUSTAKA}

Geraldo, M. (2017). Laporan PKL Muhammad Geraldo.

K. Barbe, W. V. M. and D. S. (2012). Analyzing the Windkessel Model as a Potential Candidate for Correcting Oscillometric Blood-Pressure Measurements. IEEE Transactions on Instrumentation and Measurement, 61(2).

M. Singh and N. Jain. (2016). Performance and Evaluation of Smartphone Based Wireless Blood Pressure Monitoring System Using Bluetooth. IEEE Sensors Journal, 16(23).
S. Ahmad et al. (2012). Electrocardiogram-Assisted Blood Pressure Estimation. IEEE Transactions on Biomedical Engineering, 59(3).

S. Ando. (2014). What does a perfect blood pressure meter look like from a clinician point of view? IEEE Instrumentation \& Measurement Magazine, 17(3).

S. Baktash et al. (2017). Characteristic Ratio-Independent Arterial Stiffness-Based Blood Pressure Estimation. IEEE Journal of Biomedical and Health Informatics, 21(5).

S. Huang, P. Hung, C. H. and H. W. (2014). A New Image Blood Pressure Sensor Based on PPG, RRT, BPTT, and Harmonic Balancing. IEEE Sensors Journal, 14(10).

S. Liu, T. Lin, D. C. and J. W. (2015). Assessment of Stroke Volume From Brachial Blood Pressure Using Arterial Characteristics. IEEE Transactions on Biomedical Engineering, 62(9).

Sukardi. 2004. Metodologi Pengabdian Pendidikan. Jakarta: PT. Bumi Aksara.

T. M. Seeberg et al. (2017). A Novel Method for Continuous, Noninvasive, Cuff-Less Measurement of Blood Pressure: Evaluation in Patients With Nonalcoholic Fatty Liver Disease. IEEE Transactions on Biomedical Engineering, 64(7). 